\title{
Student nurses' needs for developing basic study skills
}

\author{
M Fischer, Department of Nursing Science, University of the Western Cape \\ ELD Boshoff, Department of Nursing Science, University of the Western Cape \\ VJ Ehlers, Department of Advanced Nursing Sciences, UNISA
}

\section{Opsomming}

Een van die hoof verantwoordelikhede van die verpleegopvoeder is om verpleegstudente te help om selfgerigte studievaardighede te ontwikkel wat hulle in staat sal stel om die nodige inligting te bekom, te verwerk, toe te pas en te integreer in die verpleegpraktyk.

Die ontwikkeling van bogenoemde studievaardighede impliseer nie slegs ' $n$ multidimensionele benadering tot die student in totaliteit nie, maar vereis ook voortdurende en bestendige betrokkenheid van die student by haar/sy eie leerproses. Laasgenoemde veronderstel ook dat studente oor sekere essensiële vaardighede relevant tot leer en studeer sal beskik. Volgens die literatuur is dit klaarblyklik dat sekondêre skoolopleiding, skoliere oor die algemeen, nie voldoende voorberei vir tersiêre onderwys nie.

Hierdie navorsing is uitgevoer in 'n poging om antwoorde te vind op die vraag of studentverpleegkundiges leiding benodig met betrekking tot die ontwikkeling van spesifiek geïdentifiseerde stdievaardighede, en indien leiding wel voorsien word, of dit voldoende is?

' $n$ Beskrywende opname is gedoen om bogenoemde vraag aan te spreek. Die navorsingsinstumente (vraelyste) is deur verpleegdosente en deur verpleegstudente voltooi (gedurende 1997) in die Wes Kaap.

Na die voltooiing van die analisering en interpretering van die data het die navorser tot die gevolgtrekking gekom dat die verpleegstudente ' $n$ duidelike behoefte ervaar met betrekking tot meer leiding aangaande die ontwikkeling van basiese studievaardighede en dat bestaande akademiese ondersteuningsprogramme nie laasgenoemde behoeftes doeltreffend aanspreek nie. Dit het ook voorgekom dat die taalmedium van die voorgeskrewe studie materiaal ' $n$ diepgaaande impak op die leer en studie prosesse van die studente het, veral die verstaanbaarheid van die taal van sommige voorgeskrewe bronne.

Verskeie aanbevelings, verbandhoudend met verskeie fasette van die onderrig/leer situasie, is gedoen ten einde studente se leer- en studievaardighede te verbeter. Die bemeestering van die vaardighede kan beskou word as belangrike voorvereistes vir effektiewe, verantwoordelike, onafhanklike professionele praktykvoering.

\section{Summary}

One of the key responsibilities of the nurse educator is to develop student nurses' abilities regarding self-directed study. Self-directed study requires inter alia, the ability to find information, synthesis and consequent application and integration of the information in practice.

The development of the abovementioned skills does not only imply a multidimensional approach to the student in totality, but also requires the meticulous involvement of the student in her/his own learning. The latter also assumes that students possess certain essential skills relevant to learning and studying. From the literature it is evident that secondary schooling in general, does not prepare students adequately for tertiary education.

This research intended to find answers to the questions whether student nurses require guidance regarding the development of specifically identified study skills, the guidance provided and whether the guidance provided was sufficient.

A descriptive survey was done in order to address the above questions. The research instruments (questionnaires) were completed (during 1997) by nurse educators and student nurses in the Western Cape.

On completion of the analysis and interpretation of the data, the researcher concluded that student nurses expressed a need for more guidance regarding the development of basic study skills ant that existing student support programs did not address all these needs adequately. Furthermore, it was concluded that the language medium of the prescribed study material had a profound effect on the learning and study proceses of student nurses.

Based on the conclusion, various recommendations were made concerning different facets of the teaching/learning event., in order to enhance students' learning and studying skills.

Mastery of these skills can be regarded as being important prerequisites for effective, responsible, independent professional practice.

\section{Introduction}

When student nurses commence their training, they enter a complex situation. They are expected to meet the tertiary education requirements (in college or university) as well as to fulfil the expectations in the clinical nursing situations. Thus student nurses are expected to simultaneously enter two strange worlds with unique demands - the tertiary education situation and the clinical health care situation.

In education, in general, and in nursing education, specifically, the focus is on the student and on learning as a unique experience. It is not the how much was taught that is important but the how much learning that occurred, that is of the utmost importance. This is the most important aspect determining stu- 
dent nurses' success in mastering the theoretical components of their programs. Thus the most important task of nurse educators could be regarded as enabling students to improve their learning, to teach students how to learn as effectively as possible. This task becomes ever more important as teaching moves away from the conventional classroom situations, placing greater emphasis on learning experiences, emphasising learning outcomes or abilities, rather than teaching objectives. (Quinn 1988:234). Students who have mastered study skills would be better able to make effective use of both theoretical and clinical learning opportunities, than those who have not done so. Therefore the focus of this research was on whether nursing students have a need regarding the ability to develop basic study skills, and whether adequate assistance in this regard was available or not.

\section{Research question}

The mastery of study skills enhancing autonomy is an essential prerequisite for becoming effective independent nurse practitioners. This aspect was not emphasised in conventional nursing education programmes which demanded theoretical knowledge about diseases, the passing of theoretical and practical examinations and the rotation through specific clinical units (Ewan \& White 1984:11). This traditional "content" emphasis in nursing education is being replaced by an approach emphasising the development of students' abilities to find information, synthesise this information and utilise it for solving problems (Chakrabarty 1983:170). Students who lack the skills to obtain, synthesise and apply information may experience grave problems. Nurse educators who teach students to master and/or enhance these skills, will greatly contribute towards the students' ultimate success. On the other hand, disregarding the students' abilities or inabilities to use study skills, might severely limit the benefits which students can derive from the theoretical and clinical learning situations (Powell 1981:78).

In order to plan effective teaching and learning opportunities for students it is essential to compile a profile of the students. This is essential to ensure that the students' needs and expectations will be met by the planned learning opportunities. Education specialists stress the importance of lecturers' knowledge about their students' learning abilities/disabilities when they embark on tertiary education courses (Beard \& Hartly 1986:92; Jacobs 1992:39; Luthuli, Maseia \& Zuma 1992:32). According to Luthuli et al (1992:31-32) large numbers of Black students in the Republic of South Africa (RSA) might lack the basic study skills required for the successful transition from secondary to tertiary education systems. Lecturers who help students to master study skills, taking into account their advantaged or disadvantaged school backgrounds, will indeed enhance these students' chances of successfully completing their studies and of becoming independent nurse practitioners. These study skills include the ability to read, write, organise materials, and the utilisation of the available study time. "The concept of an independent learning ability is underpinned by many traits, such as intrinsic motivation, a reading ability, an ability to comprehend, the ability to relate to ideas and to be able to explore the depths of meaning" (Fransman 1995:176).

The research questions are therefore: Do student nurses have a need regarding the development of basic study skills? Is the guidance available to students to help them to develop their own basic study skills, adequate or not?

\section{Purpose of the study}

Research was conducted in an attempt to determine

- whether effective guidance is provided to diploma student nurses regarding the development of basic study skills

- $\quad$ student nurses' needs for the development of basic learning skills

- $\quad$ possible shortcomings in this regard

- whether there is a need for additional study guidance (if students do not possess the necessary basic skills) and

- $\quad$ to make appropriate recommendations to address identified shortcomings.

\section{Description of relevant terminology Active involvement}

Active involvement or active participation in learning refers to the students' ability to react actively to a particular learning experience. It includes perceptual observation, the execution of physical activities and the utilization of the thought processes.

Consequently active participation can be perceptible or concealed, where the above refers to internal responding like the formation of a mental image (Van Hoozer, Bratton, Ostmoe. Weinholtz. Craft. Gjerde \& Albanes 1990:137-138).

\section{Basic/Essential study skills}

For the purpose of this study, basic study skills are defined as those skills that are needed to find information, and to organize and utilize this information in a satisfactory and productive manner (Behrens 1991:124).

\section{Guidance}

According to Quinn (1988:418) guidance encircles the function of encouraging and support. the provision of information and advising, linkage and representation, remedial supporting and counseling.

Milner (in Behr, Cherian, Mwamwenda, Ndaba en Ramphal 1986:112-113) define guidance in education as the presentation of knowledge, information and/or advice to individuals or groups in a structured manner in order to provide adequate material on which choices can be based.

\section{Meta-cognition}

Meta-cognition (reflection) comprises knowledge regarding the human beings' internal cognition processes. There is certain meta-cognition strategies that can help the student to learn and study more effectively.

According to Slabbert (1993:39) meta-learning is the activity of a student that is conscious of her/his learning process and who plans, implements, monitors and evaluates her/his studies purposefully.

Meta-cognitional knowledge implies cognitive control strategies such as the formulation of goals, the determination of whether additional knowledge is necessary, the evaluation of implemented strategies and self-motivation (Gravett 1993:65). 


\section{Nursing education}

Nursing education is education through which students are guided, assisted and provided with ways, that will enable them to learn the art and science of nursing in order to apply the above in the nursing of people needing nursing care (Mellish and Brink 1986:6).

\section{Student nurse}

A student nurse is an individual who is registered as a student at a nursing college according to Regulation 425 of 22 February 1985 as amended which leads to registration as a nurse practitioner (general, psychiatric and community-) and midwife

\section{Support}

According to the Universal Dictionary (1987:1521) support is defined as an action "... to encourage or lend strength to, especially in difficulties, to provide for or maintain by supplying with money or other necessities".

\section{Research Design}

An exploratory descriptive study was done utilising quantitative methodology.

\section{Research populations and samples}

As this research focused on both student nurses and nurse educators, both these populations and samples required identification. In order to obtain the best results possible random sampling was not done. Out of the population of 1,319 student nurses , 80 per cent (1055 students) could be reached at the four colleges. Questionnaires were handed to 1055 student nurses, comprising the 80 per cent convenience sample of student nurses for this investigation.

\section{Student nurses}

The population for this study comprised 1319 student nurses pursuing the comprehensive Regulation 425 of 25 February 1985, as amended, (R425) nursing course at four nursing colleges in the Western Cape, situated within the metropolitan area of Cape Town, during 1997. No distinctions were made on the basis of language, ethnicity, or the level of training, as this research aimed merely at identifying student nurses' study skills and possible deficiencies in this regard, not at comparing these skills and deficiencies between first, second, third and fourth year students.

Out of this population of 1319 student nurses, 80 per cent (1055 students) could be reached at these four colleges during 1997. Questionnaires were handed to 1055 student nurses, comprising the 80 per cent convenience sample of student nurses for this investigation.

Questionnaires were distributed according to the total number of nursing students at a specific nursing college.

\section{Nurse educators}

The 94 registered nurse educators who were involved with teaching these student nurses comprised the population of nurse educators for the purposes of this investigation. (Vacant posts were disregarded for the purposes of this investigation).
Due to the relatively small population (94 nurse educators) questionnaires were distributed amongst all 94.

\section{Permission to conduct the research}

Written permission to conduct this research project was sought and obtained from the Director of Hospital Services of the Western Cape Province and from the individual principals of the four nursing colleges participating in this research. Each student and each nurse educator who participated in this research by completing a questionnaire did so voluntarily without any coercion whatsoever in his/her own time. The questionnaires were answered anonymously.

\section{Literature study}

A comprehensive literature study was done to develop sufficient background information about the acquisition, synthesis and reproduction of knowledge. The literature study was based on information obtained from the Medical Research Council (MRC), and from retrieving relevant sources from computer printouts obtained from ERIC (Educational Resource Information Centre). Keywords used in the literature search included Educational Psychology, Didactics, and Nursing Education. The lists of references of studied articles and/or books were further explored to obtain information relevant to student nurses' needs for developing basic study skills.

Due to the length of this research report, an actual literature review as such is not included. In discussing the research findings, cross references to similar and/or dissimilar research results encountered in the literature overview will be provided in an attempt to link the current research project's findings to those of previous research reports.

\section{Research instruments}

Two computer coded questionnaires, based on the knowledge derived from the literature study, were used to collect data from student nurses and from nurse educators, in an effort to identify student nurses' needs for developing basic study skills. A questionnaire is a printed self-report form designed to elicit information that can be obtained through uritten responses of the subject... Questionnaires can be designed to determine facts about the subject or ... facts about events or situations known by the subject; or beliefs, attitudes, opinions, levels of knowledge or intentions of the subject (Burns \& Grove 1987:311). Questionnaires were deemed suitable for this specific survey because all the respondents could read and write and could be reached relatively easily at the four nursing colleges during 1997. The respondents could complete the questionnaires in their own time, limiting the time invested by the four colleges in this research project.

In an attempt to limit some of the disadvantages of using questionnaires, namely the inability to clarify questions and to probe answers, great efforts were invested in designing questionnaires containing closed-ended questions about specific teaching-learning aspects, but also by including open-ended questions where the respondents could provide their personal views, experiences and/or perceptions. Both questionnaires allowed the respondents to provide general comments.

Both questionnaires were designed in Afrikaans, translated 
into English and translated back into Afrikaans in an effort to obtain maximum consistency between these two languages. Each questionnaire contained both the Afrikaans and English versions. The questionnaires were discussed with nurse educators who did not form part of the research population.

\section{Questionnaire administered to student nurses}

This questionnaire consisted of two sections, with the first section seeking autobiographic information, and the second section trying to obtain information about the students' academic backgrounds, experiences, and needs to develop basic study skills, addressing the following aspects:

- $\quad$ academic background

- degree of difficulty of the course

- $\quad$ work load

- $\quad$ language issues

- basic study skills; including study guidance received by students, study skills and methods utilised, specific problems encountered by students and their needs for additional study guidance.

\section{Questionnaire administered to nurse educators}

This questionnaire also comprised of two sections, aiming to obtain information about the nurse educators' biographic data and about their perceptions of the student nurses' study habits and skills.

\section{The validity and reliability of the questionnaires}

The validity of an instrument is regarded as its ability to measure that which it purports to measure or to test what it is supposed to test (Gay 1981:137). The questionnaires' content validity was based on the grounds that the questions were derived from an in depth literature review, and in the attempts made to compare and contrast the findings of this research with those of other researchers reported in the studied literature. Face validity was obtained by subjecting the questionnaires to the scrutiny of an experienced researcher at the University of the Western Cape and to a number of nurse educators at this university.

The reliability of a questionnaire relates to the accuracy with which it measures that which it purports to measure. The reliability of an instrument indicates the proportion of accuracy to inaccuracy in its measurements. Reliability is usually defined as the ability of the data-gathering device to obtain consistent results (Treece \& Treece 1986:253). In order to establish the accuracy of the instruments' measurement a pretest was conducted on a group of 110 student nurses and 12 nurse educators, whose characteristics corresponded with those of the target populations, but who did not form part of the research populations.

Through this pretest of the instrument, the following aspects were also established:

- the time required to complete the questionnares

- $\quad$ clarity of the instructions

- ability to understand the questions.

Based on the results of the pretest a number of modifications were implemented to enhance the comprehensibility of the questions and to reduce wrong interpretations during the implementation of the actual research. A trial computerised analysis was done of the data obtained during the pretest to identify any problems in this regard. No alterations were required in this respect.

\section{The administration of the questionnaires}

The researcher delivered the questionnaires to the principals of the four nursing colleges which participated in this research. The principals distributed the questionnaires to the student nurses and to the nurse educators. The completed questionnaires were placed into a specific container in each college, collected by the researcher on specific predetermined dates. Unfortunately one college failed to produce any completed questionnaires, probably due to shortages of nurse educators and continued student unrest experienced at this college. After a period of three months had expired, without any completed questionnaires received from this college, all further attempts to obtain responses from the estimated 400 student nurses (30.32 per cent of the population) and 15 nurse educators ( 15.95 per cent of the population) were abolished. It could not be determined to which extent, if any, the lack of responses from this college might have influenced the data obtained during this survey to identify student nurses' needs for developing basic study skills.

\section{Data analysis}

A statistician from the University of the Western Cape analysed the data obtained from the completed questionnaires using the Statistical Package for the Social Sciences (SPSS). The statistician also assisted in ascertaining that the questionnaires were indeed computer compatible prior to and after pretesting the instruments.

\section{Research results}

Questionnaires were returned by 418 student nurses (31.69per cent of the population), but 10 questionnaires had to be discarded because they contained too few responses. Thus the number of usable questionnaires amounted to $408(n=408$ implies that the sample comprised 30.93 per cent of the target population) but not all responses add up to 408 because a number of respondents failed to answer all the questions.

One of the 28 completed questionnaires received from the nurse educators had to be discarded because this person indicated that she was not involved with teaching the basic (R425) student nurses, but taught post basic courses. Thus the number of usable questionnaires received from nurse educators amounted to 27 ( 28.72 per cent of the target population).

The research results, obtained from student nurses and nurse educators in the Western Cape, will be presented together with brief interpretations and discussions from both groups of respondents whenever possible, in an effort to enhance the meaningfulness of the research results. Furthermore references to similar and/or dissimilar results reported by others in the literature reviewed will be provided in an attempt to link this project's results to those of previously reported research projects addressing the same issues. 


\section{Student nurses' ages and marital status}

Seventy-six per cent $(n=408)$ of the student nurses' ages ranged between 19 and 24 years. This age range complies with the expected one because students complete their schooling at the ages of $17-19$ and the R425 comprehensive course lasts a minimum of four years. Only 15 respondents ( 4 per cent) were older than 31 years of age, but it could not be established whether they pursued other careers and/or studies prior to becoming student nurses. Only nine per cent of the respondents were married and one per cent divorced (Fischer 1997:7582). It could be presumed, but not proven on the grounds of these research results, that married students might have less time available for their studies than their unmarried colleagues because of their obligations to fulfil their roles as wives and housewives in addition to being student nurses.

\section{Student nurses' academic qualifications}

In order to be admitted to a the R425 diploma course, students need to possess a standard 10 , or grade 12 , certificate. Out of the 405 respondents who indicated their scholastic qualifications, 77 per cent (313) possessed matriculation exemption certificates. However, having passed grade 12 , is no guarantee that students will have mastered basic study skills (Ferron 1990:92).

\section{Student nurses' home languages}

The majority ( 65 per cent) of the respondents indicated that their home language was Afrikaans, whilst 19 per cent indicated English and 16 per cent Xhosa, Sesotho, Zulu, Setswana or German to be their home languages. Students not taught in their home languages might experience problems during the second phase of the learning process, namely concept formation. They might also experience problems in formulating their thoughts into words, and in reproducing the learned materials, in a language which is not their mother tongue. More than half of the lecturers ( 52 per cent) indicated that the students had no choice concerning the language medium of instruction, although 54 per cent indicated that they taught in both English and Afrikaans whilst 8 per cent taught in Afrikaans only and 38 per cent in English only (Fischer 1997:82). As many as 370 (91 per cent) of the students indicated that they experienced problems in coping with the prescribed books, whilst 81 per cent of the lecturers indicated this to be the case (Fischer 1997:84). The students reported that they spent much time and effort trying to understand. translate and summarise the prescribed materials, and sometimes arrived at incorrect conclusions based on these translations. These findings seemed to emphasise that the mastering of reading skills is a prerequisite for effective learning. By developing their reading abilities, students could be helped to minimise their learning and studying problems (Greyling \& Joubert 1989:2). Reading involves two actions: a visual one of recognising the printed words and a non-visual one of grasping the meaning portrayed by the words - which depends on the individual person's general knowledge of the written language (Machet 1991:91). A reader with a limited knowledge of the specific language will attempt to read and understand each word whilst one with a good command of the language will read and understand sentences or concepts, even if some words are unknown. Nurse educators do have important roles to play in helping students to enhance their reading and comprehension skills, as indicated by the 91 per cent of respondents who reported experiencing language problems during their studies. Acquiring effective language skills in mastering basic learning skills cannot be overemphasised in the RSA with its eleven official languages. The ability to acquire meaningful knowledge is related to the ability to form concepts and to formulate appropriate frames of reference; both processes will be hampered in cases where students need to study in their second or third language. Effective reading skills are inextricably intertwined with the ability to learn and study effectively (Greyling \& Joubert 1989:120-122; Maxwell 1981:269274).

\section{Student nurses' perceptions of their academic workloads}

A total of 305 ( 75 per cent) of the student respondents indicated that they perceived the theoretical work loads as being excessive (Fischer 1997:87). Courses with huge workloads might encourage reproductive learning orientations, impeding the development of reflective and creative learning activities (Buzan 1993:1; Schaap \& buys 1995: 132). A reproductive learning orientation might develop whereby students memorise facts, pass tests and examinations and forget the facts. Buzan (1993:11) aptly describes this problem as “... the typical student's pilgrom's progress: the slow realisation that the volume of academic work is increasing and that the brain is starting to buckle under the strain of all the thinking, creativity, memory, problem-solving, analysis and writing required ... (students begin) ... to experience not only diminishing returns but accelerated non-returns".

Learning to provide effective nursing care to patients/clients can never be accomplished by merely memorising facts, students need to reflect on the application of knowledge to the unique health care needs of individual persons, and to design the best possible nursing care plans on the basis of such information, implement nursing procedures and evaluate the results of such implementations. Gwele \& Uys (1995:9) report that the realisation of the $\mathrm{R} 425$ programme objectives could be jeopardised by teaching certain subjects too extensively and by adhering to an overloaded and rigid curriculum. According to Esterhuizen (1989:94-96) and Heighway (1991:18) basic nursing education curricula tend to be overloaded in the RSA, apparently supported by the perceptions of this research projects' participating student nurses.

\section{The planning of study programmes}

Although 23 ( 85 per cent) of the nurse educators indicated that they provided guidance about the planning of study programmes, only 259 (60 per cent) of the student nurses indicated that they received such guidance, whilst 158 ( 40 per cent) indicated that they failed to receive any guidance whatsoever (Fischer 1997:89). Although specific reasons for these apparent discrepancies could not be ascertained during the research, some reasons might include that the educators only provided guidance when requested to do so, when they identified study problems or when they introduced new modules.

The majority of the students ( 270 or 66 per cent) did not plan 
their study activities on weekly bases, and did not work according to any timetables. The effective management of time might be the most crucial factor determining the success or failure or adult students' learning endeavours (Moletsane 1992:107). Based on the results of this research project, student nurses might benefit from planning their studies more effectively according to realistic schedules in accordance with their unique capabilities, needs and priorities - requiring self knowledge. Acquiring such self knowledge has been described as the most important skill to be mastered by any student (Chibnall 1987:117; Nisbet \& Shucksmith 1991:vii). Based on the research results of this survey, student nurses in the Western Cape could decidedly benefit from acquiring the skill of planning their studies more effectively and from adhering to realistic study programmes.

\section{The taking of notes}

According to the data obtained from the nurse educators' questionnaires, 12 (48 per cent) of the nurse educators provided some guidance to students concerning the taking of effective notes during lectures. Concurrently 193 (47 per cent) of the student nurses reported having received such guidance (Fischer 1997:93). However, 200 (96.15 per cent) students reported experiencing difficulties with taking effective notes. Students' comments in this regard included that

- they were unable to listen and write simultaneously

- the lectures were presented too fast

- $\quad$ they were unable to write down the schemata provided on transparencies

- they wanted to write down extensive notes because they were unable to extract the significant aspects only.

Students' comments indicated that lecturers could significantly assist students to pay more attention during lectures and to compile more effective lecture notes, if the lecturers could provide photocopies of their transparencies to the students. This would enable students merely to add salient facts to the frameworks provided and would enable them to listen more attentively during lectures.

The primary purposes of taking notes are to enhance the memory of facts, to improve concentration, and to facilitate the revision process provided the notes have been organised to fit into the individual student's study approaches (Freeman 1989:42). Notes made during lectures require further revisions and refinements in order to become a meaningful part of the student's repertoire of knowledge. The quality of these notes usually depends on the skill of the student, the lecturer's presentation style and the subject contents. It would seem probable that students' note taking, and possibly also their mastery of the contents presented during lectures, could be considerably enhanced if lecturers would supply photocopies of their transparencies to all students.

\section{Reading skills}

Questions in this regard focused on students' abilities to condense reading materials and other specific activities required such as survey reading. The students' responses indicated that

- 45 per cent encountered problems in identifying key concepts in reading materials
- $\quad 30$ per cent could not identify recurrent themes

- 25 per cent were uncertain whether they had mas tered these skills or not

- $\quad 37$ per cent studied the information contained in graphs, diagrams and tables

- $\quad 40$ per cent studied the summaries at the end of chapters in books (Fischer 1997:99-102).

Out of the 27 nurse educators, 25 ( 93 per cent) considered student nurses to be experiencing reading problems, and lacking reading skills (Fischer 1997:103). It could not be ascertained from the available data whether these students' reading problems could be attributed to a lack of language skills and/or to non-critical, non-questioning approaches adopted towards reading. Students who cannot decode the key concepts from reading materials can be expected to encounter problems with concept formation (Gilles \& Bixby 1989:22; Greyling \& Joubert 1989:22). Nurse educators who could assist student nurses to read critically, and summarise the material meaningfully would enhance the students' basic studying and learning skills

\section{Library skills}

The responses indicated that

- $\quad 93$ per cent of the nurse educators provided guidance concerning library use

- $\quad 67$ per cent of the student nurses received guidance about library use

- $\quad 47$ per cent of the student nurses required further guidance to use the library more effectively

- 69 per cent of the student nurses spent less than one hour per week in the library (Fischer 1997:104-108).

The apparent discrepancy between the nurse educators' indications that they provided guidance about library use, and the students' reports about receiving such guidance could not be accounted for. However, this apparent lack of library skills among students in the RSA have also been reported by Behrens (1991:126), Bouwer (1985:39) and Esterhuizen (1989:71-72).

College libraries which are only open from 08:00 until 14:00 during weekdays might not succeed in serving the student nurses' information needs. This implies that students can only use the libraries during designated college periods but never during their free time.

\section{Skills for the writing of assignments}

Students encountered numerous problems in writing assignments, including that

- 61 per cent of the students struggled to put their thoughts into written words

- $\quad 55$ per cent of the students could not reproduce the available information in their own words

- 45 per cent of the students did not receive guidance in compiling a bibliography

- $\quad 33$ per cent of the students received no guidance concerning the use of references in the texts

- $\quad 89$ per cent of the nurse educators considered the students to lack writing skills

- 85 per cent of the nurse educators indicated that the students' lack of language skills adversely affected 
their academic achievements (Fischer 1997:108-111).

The problems reported by student respondents in this survey, seemed to correspond with those reported by Casey (1989:49) who reiterated that one of the benefits of writing assignments is that it affords students the opportunity to express their thoughts and knowledge in their own words. Thus it is of the utmost importance that nurse educators should assist students to master the skills required for writing assignments.

\section{Examination skills}

Students' responses to the questions concerning their examination preparation seemed to concur with the previously reported absence of long term study programmes, using reproductive learning styles, and excessive amounts of material to be mastered. The students' responses indicated that

12 per cent commenced studying one or two days;

43 per cent one week and only 33 per cent two or three weeks prior to examinations

- $\quad 57$ per cent prepared for examinations by memorising the contents

- 63 per cent worked out answers to previous examination papers

- 49 per cent scheduled their studying times

- 49 per cent prepared core summaries

- $\quad 37$ per cent attempted to predict ("spot") examination questions

- $\quad 51$ per cent read all examination questions

- $\quad 30$ per cent used frameworks to answer questions

- $\quad 42$ per cent scheduled their time for answering questions and for revising their answers

- 63 per cent encountered problems in answering the questions within the time allocated (Fischer 1997:113117).

In answering objective item questions, the students indicated that

- $\quad 53$ per cent did not consider all the provided alternative answers

- $\quad 52$ per cent did not look for specific cues

- $\quad 78$ per cent did not attempt to use information from other items in seeking specific correct answers (Fischer 1997:118-119).

Based on the above data, students seemed to require guidance in preparing more effectively for examinations, using the time during the examinations more effectively and approaching examinations less mechanistically. The majority of the respondents apparently lacked the skills required for successfully writing examinations, in answering both essay type and objective type examination questions.

\section{Limitations}

The generalisation of the results obtained from this exploratory descriptive survey could be limited because

- $\quad$ the survey was conducted only in the Western Cape Province of the RSA

- $\quad$ only 10 second year students responded

- $\quad$ one college failed to return any completed questionnaires
- $\quad$ no distinctions were made between first, second, third and fourth year students' responses - such distinctions might yield meaningful insights during further research.

\section{Recommendations}

The students who participated in the survey apparently lacked basic study skills and could benefit from guidance and assistance in developing:

- realistic short- and long term study programmes

- $\quad$ enhanced language skills, including reading-, writing and comprehension skills

- $\quad$ their skills in utilising libraries more frequently and more effectively

- critical, questioning approaches to reading and studying

- $\quad$ their skills to compile meaningful notes during lectures and refine these later on

- their competencies to write assignments

- their skills in preparing for examinations

- their skills for actually answering essay type and objective item examination questions (Fischer 1997:126-129).

Further aspects which need to be addressed to enhance student nurses' development of basic study skills include

- a critical evaluation of the curriculum and of specific subjects' syllabuses

- $\quad$ specific attempts to enhance students' basic study skills

- $\quad$ ensuring that students accept responsibility for their own academic development

- $\quad$ systematic evaluations of classrooom practices ad hered to in nursing colleges

- utilising teaching methods which require more independent student activities

- $\quad$ the provision of student counselling and support services (Fischer 1997:131-133).

\section{Conclusion}

This survey's results indicated that student nurses in the Western Cape Province of the RSA lacked basic study skills and required assistance and guidance to develop into independent students and ultimately into independent professional nurse practitioners capable of being responsible and accountable for their own acts and omissions. It appears to be extremely important that student nurses should be taught "how to learn" in order to progress towards independent self-directed learning to realise the ultimate goal of becoming practising professional nurses. Unless nurse educators can assist student nurses to develop basic study skills, many of these students might be unable to learn and thus unable to become registered professional nurses. Ultimately the success of nurse educators' teaching efforts might depend on their abilities to enable their students to develop their basic study skills.

A conclusive remark from Bassano (as quoted in Fischer 1997:139) seems to summarise the essence of this research: 
Unless the student can communicate "Who I am and what I am used to" and the teacher can communicate "Who I am and why I do what I do", it stands to reason that the students may perceive their ... instructor as incompetent in ... training, and our students may seem to us a roomful of unco-operative malcontents.

\section{List of references}

BEARD, R \& HARTLY, J 1986: Teaching and learning in higher education. St Louis: Harper \& Row.

BEHRENS, SJ 1991: Library literacy and undergraduate students. SA Journal for Higher Education (SAJHE), 5(1): 124-128.

BOUD, D 1981: Developing student autonomy. Triptree Essex: Anchor.

BOUWER, MJC 1985: Verpleegonderwys in adragogiese perspektief met besondere verwysing na die verantwoordelikheid van die student. Unpublished M Cur dissertation. Pretoria: University of Pretoria.

BURNS, N \& GROVE, SK 1987: The practice of nursing research: conduct, critique and utilization. Philadelphia: WB Saunders.

BUZAN, T 1993: The mind map book. London: BCA.

CASEY, F 1989: How to study: a practical guide. London: MacMillan.

CHAKRABARTY, E 1983: Research in nursing: school of nursing libraries as information resources for nurse education, in Research into nurse education edited by Davis, BD. London: Croom Helm.

CHIBNALL, B 1987: Teaching for effective study. London: Croom Helm.

DAVIS, BD (ED) 1983: Research into nurse education. London: Croom Helm.

ESTERHUIZEN, JM 1989: 'n Ondersteuningstelsel vir studentverpleegkundiges. ' $n$ Verpleegdidaktiese perspektief. Unpublished M Cur dissertation. Auckland Park: Rand Afrikaans University.

EWAN, C \& WHITE, R 1984: Teaching nursing: A self-instructional handbook. London: Croom Helm.

Ferron, OM 1990: Guidance and counselling for tertiary students. Durban: Butterworths.

FISCHER, M 1997: 'n Ondersoek na die behoeftes van studentverpleegkundiges met betrekking tot die ontwikkeling van basiese studievaardighede. Unpublished MA Cur dissertation. Bellville: University of the Western Cape.

FRANSMAN, HJ 1995: Independent learning as a contribution to student achievement. SA Journal for Higher Education (SAJHE), 9(1):173-177.
FREEMAN, R 1989: Mastering study skills. London: MacMillan.

GAY, LR 1981: Educational research. Competencies for analysis and application. $2^{\text {nd }}$ Edition. London: Charles E Merril.

GILLES, C \& BIXBY, U 1989: Whole language strategies for secondary students. New York: Richard C Owen.

GREYLING, PJ \& JOUBERT, JJ 1989: Didactics: reading instruction in the junior primary phase. Kaapstad: Human \& Rousseau.

GWELE, NS \& UYS, L 1995: Views of leading nurse educators regarding the Comprehensive Basic Nursing Education Programme. Curationis, 18(1).

JACOBS, JJ 1992: 'n Profiel van die beginnerstudent in in "n beroepsgerigte kursus. SATHO, 6(2):34-40.

HEIGHWAY, V 1991: Surviving in absentia. Conference paper presented at Excellence in clinical nursing, Conference Proceedings Volume 5, 19-20 September 1991: Bloemfontein. (SANA Conference).

LUTHULI, ND, MASEIA, SE \& ZUMA, LC 1992: The hurdles faced by Black students. Nursing RSA Verpleging, 7(2):30-32.

MACHET, MP 1991: The effect of cultural background on reader response and memory of text content. SA Journal for Higher Education (SAJHE), 5(1):91-94.

MAXWELL, M 1981: Improving student learning skills. London: Josey Bass.

MOLETSANE, RIM 1992: Academic support for adult learners in tertiary institutions. SA Journal for Higher Education (SAJHE), 6(1):105-109.

POWELL, 1981: One-to-one learning in Developing student autonomy edited by Boud, D. Triptree Essex: Anchor.

QUINN, FM 1988: The principles and practice of nurse education. $2^{\text {nd }}$ Edition. London: Croom Helm.

SCHAAP, P \& BUYS, MA 1995: Universiteite en onafhanklike leer. $S A T H O, 9(1): 128-141$.

TREECE, EW \& TREECE, JW 1986: Elements of research in nursing. $4^{\text {th }}$ Edition. St Louis: CV Mosby. 